\title{
The Job Stress Intervention Matrix: A New Conceptual Framework for Higher EdUCATION IN THE POST-COVID World
}

${ }^{*}$ Barry A. Friedman, Elizabeth Keida, and Najah Zaaeed

Barry A. Friedman, School of Business, 247 Rich Hall, State University of New York at Oswego, Oswego, New York 13126 (barry.friedman@oswego.edu

Elizabeth Keida, Assistant Professor, Department of Health Promotion and Wellness, State University of New York at Oswego 7060 NY-104 13126

Najah Zaaeed, Assistant Professor, Department of Health Promotion and Wellness, State University of New York at Oswego 7060 NY-104 13126

* Corresponding author. Authors names appear in alphabetical order.

\section{Abstract}

Due to the current COVID-19 pandemic, faculty stress in higher education is high as a result of the transition from face-to-face to alternative teaching modalities. Excessive stress significantly decreases employee productivity and costs organizations an annual 
estimated $\$ 300$ billion in medical bills and lost productivity. In higher education, research has focused more on student rather than faculty stress, and a comprehensive stress management model for faculty is conspicuously missing from the literature. We propose a new conceptual framework that incorporates two otherwise disparate concepts: Social Ecological Model (SEM) and Feldman's employee socialization stages. At each socialization stage and SEM level, we advocate that higher educational institutions reduce faculty powerlessness that leads to dysfunctional stress. We offer implications for faculty health, productivity and efficacy, as well as higher education organizational effectiveness.

Keywords: stress, social ecological model, socialization, higher education, workplace health promotion

DOI: https://dx.doi.org/10.15239/j.brcacadjb.2021.11.01.ja03

\section{INTRODUCTION}

Job stress remains the major source of stress in American adults (American Institute of Stress, 2020a,b). Job stress results in an estimated $\$ 300$ billion annual cost in medical bills and lost productivity, $44 \%$ of Americans report greater job stress than 5 years ago, one in five report extreme stress, and three of four doctor visits are driven by stress related ailments (American Institute of Stress, 2020c; Street \& Lacey, 2019).

Research shows the feeling of powerlessness rests at the core of many of these workplace stressors (Bandura, 2004; Kangos, et al., 2018; Lim et al., 2018; Wallerstein, 1992). Powerlessness is studied in other disciplines, predominantly healthcare with respect to patients' psychological and physical response to debilitating injury and disease (Chen \& Yang, 2010). Glasberg et al. (2007) found that healthcare managers experienced powerlessness and a feeling of "spiraling inadequacy" in a work environment characterized by constant reorganization, staff reductions, high performance expectations, reduced resources, and increased workloads. Powerlessness is shown to be linked to bullying (Hurley et al., 2016), 
alienation (Özer et al., 2019), patients that self-harm (Rayner et al., 2019), older patients (Chen et al., 2019) and stroke victims (Lin \& Li, 2019). Increased competitiveness driven by domestic competitors and globalization, workloads that are more demanding, poor management, dysfunctional conflict, job insecurity, mergers and acquisitions, low pay growth and decreased employee benefits, and many other factors will likely exacerbate job stress (APA, 2011; Kinchen \& Victoria, 2019; Knežević and Krstić, 2019; Vander, et al., 2012). Feelings and implications of powerlessness and stress are present in higher education (Walkington, 2017), and they may have been exacerbated since the COVID-19 pandemic.

While higher education faculty stress has been discussed for decades, examination and discussion regarding the increasing rate of high stress levels among faculty is a relatively new phenomenon (Darabi, Macaskill, \& Reidy, 2017). Although empirical data indicate stress among higher education faculty exists (Faisal, 2019), professors continue to be considered as having low stress jobs by the general public, job search entities, and by professors themselves (Renzulli, 2019; SHRM, 2015). CareerCast, a job search and career guidance organization, rated jobs along stress related dimensions including physical demands, deadlines, competitiveness, travel, working in the public eye, and placing oneself at risk. Additionally, teaching in higher education was still viewed as one of the least stressful jobs in March of 2019 (Min, 2019). However, several pre-COVID-19 studies ranging from 2015 to 2019, indicate that stress among academics due to factors such as administrative non-teaching loads, teaching loads, feelings around research/scholarship, support systems and toxic workplace was increasing (Mariais, Lantheaume, Fiault \& Shankland, Al-Taweel et al. (2020); 2020; Faisal, 2019; Jacobs \& Winslow, 2016).

COVID-19 changed these ratings as teaching transitioned to alternate modalities. Social distancing forced many universities to transition from face-to-face instruction to synchronous, asynchronous or hybrid online teaching. Professors did not make the 16 least stressful professions in a most current survey (LaPonsie, 2020). In fact, faculty stress levels have 
increased since the COVID-19 pandemic, even more for early career/ new hire faculty (Flaherty, 2020). By default, the transition to online teaching incorporates a number of significant challenges that many universities, faculty or students were not prepared for. Adding to this, were COVID-19 stress related factors regarding meeting expectations and sudden changes related to teaching, scholarly work, and securing funding for research. In addition to this is the growing concern of institutional support systems and uncertainty of tenure and job security, all of which may increase marginalization of underrepresented faculty, as well as anxiety powerlessness, and contemplation of career changes for many.

Plessis \& Martins (2020) stated that these pressures have many negative consequences including substandard teaching, poor student learning, and even professors leaving the field. These authors developed an instrument that measured nine coping mechanisms that faculty use to deal with stressors: "social support, religious, cognitive, active leisure, avoidant, social disengagement, vacation time, rumination and emotional coping" (Plessis $\&$ Martins, 2020, 10). For example, professors can turn to religion, the support of others, exercise or meditation to help manage stress. These coping mechanisms stem from faculty themselves and not their universities. Stress management is a shared accountability between faculty and their universities; however, the extant literature does not have a comprehensive framework for universities to responsibly provide stress management opportunities for faculty throughout their place of employment. Previous research has focused on the stress experienced by students during the transition to remote learning, including "technical platform issues, teachers lack experience teaching online, and their teaching style improperly adapted to the online environment" (Coman et al, 2020, 1; Rizun, 2020). This article focuses on higher education faculty stress management rather than students.

To meet the need for a comprehensive higher education faculty stress management framework, we propose the Job Stress Intervention Matrix (JSIM)- an original conceptual framework that incorporates otherwise 
disparate psychological models: Feldman's (1981) employee socialization stages and the Social Ecological Model (Bronfenbrenner, 1979). At each stage of employees' socialization and SEM level, we advocate that institutions of higher education reduce faculty dysfunctional stress by empowering, reducing powerlessness and increasing control over their work environments. Few comprehensive long-term studies explore a systematic approach to addressing job stress. A notable exception was completed at the University of Rochester over a period of five years and 16,000 employees (Pesis-Katz et al., 2020). These authors found that an integrated wellness program can reduce risks of chronic health conditions and improve overall health and quality of life (Pesis-Katz et al., 2020).

First, we review the concept of powerlessness and stress, Feldman's Employee Socialization and the SEM models. The JSIM is then proposed. We then detail organizational interventions appropriate for various JSIM cells and offer interventions throughout the faculty career. We conclude with implications for faculty health, increased productivity, efficacy, and organizational effectiveness.

\section{Powerlessness in Higher Education}

Powerlessness is "is a universal cause of job stress. When you feel powerless, you are prey to depression's traveling companions, helplessness and hopelessness. You don't alter or avoid the situation because you feel nothing can be done" (APA, 2011, para. 3; Miller et al., 1994). Due to the interconnectedness of our wellness attributes, powerlessness does not just have a psychological burden. There is also strain on the other dimensions of wellness (i.e., physical, spiritual, social, intellectual, and occupational) (SAMHSA, 2016).

Although few have examined powerlessness among higher education faculty and staff, the extant literature reveals common themes. Implicit in many definitions of powerlessness is the feeling of alienation, lack of control, low decision rights, low autonomy, and hopelessness, that 
is in turn associated with mental distress and illness, both physical and mental (Newton, Dooris \& Wills, 2016).

\section{Feldman Employee Socialization Model Applied to Higher Education Faculty}

Feldman's (1981) model of employee socialization is offered below as a way for universities to address powerlessness and stress that faculty experience throughout their career. For example, new faculty experience powerlessness, uncertainty and stress as they balance efforts to build new course preparations, establish a research agenda, and shape new relationships with colleagues. Later, faculty often experience powerlessness and stress with respect to contract renewal and for some, ultimate tenure decisions. Tenured faculty may experience powerlessness and stress as the administration expects continued research productivity, teaching excellence in addition to new expectations (e.g., mentoring new faculty, chairing departments).

Socialization occurs as individuals come to learn and appreciate organizational values, norms and expected behavior essential for effectiveness, and the fit between an employee and his/her organization is important (Konopaske et al., 2018; Wang et al., 2011; Weeks \& Fournier, 2010). Stress can also be experienced prior to employment, during organizational entry and throughout one's career. Among the most accepted models of socialization conceptualized three stages: anticipatory, accommodation and role management (Feldman, 1981, 1976, 1967). Anticipatory socialization consists of activities an individual engages in prior to employment, including organizational research and interviewing (Greenberg, 2014). Accommodation socialization consists of onboarding activities the employees engage in during initial entry, including new employee orientation and training. Finally, role management socialization consists of resolution of longer-term conflicts of career progression, work family balance and intergroup conflict. Job stressors are found at each socialization stage. Making an informed job acceptance decision (anticipatory), 
learning a new job and work relationships (accommodation), and working long hours to achieve upward mobility while raising a young family (role management) are each potential job stressors (APA, 2011).

Poor organizational-employee fit results in poor outcomes, such as stress, high turnover intentions and low performance (Newton \& Jimmieson, 2009). In a seminal article, Rizzo et al. (1970) found that role ambiguity and conflict may result in job stress, and Chhabra (2016) found that employees' fit with organizational values mitigated the negative aspects of job stressors. Nelson (1987) was among the first to consider socialization as a stressful event, especially when employees first enter the organization. Mentoring of new teachers during this stage may be important (Paula \& Grīnfelde, 2018).

\section{Social-Ecological Model}

While Feldman's Employee Socialization Model maps stress and powerlessness at different employment stages, it does not adequately equip higher education administrators with tools to fully manage stress. The social-ecological model (SEM) can be used to effectively comprehend the depths of stress and powerlessness in the workplace, which include variables that are beyond the workplace. The SEM is used to identify and address influential factors or casualties, at multiple levels, which are sometimes interrelated (Swick \& Williams, 2006), or bidirectional and manifested in the target population's knowledge, perception or attitude towards the issue of concern (Mustanski et al., 2014). Furthermore, SEM has been used to identify determinants which prevent one from gaining knowledge, as well as changes in perceptions and motivation towards issues such as employment opportunities and advancements which can change overtime (Rosa \& Tudge, 2013). While SEM has been used to assess various types of health disparities and influences towards a population, it is evident that there is a lack of studies investigating institutional practices and its influence on the stress and well-being of staff and faculty in higher education. 


\section{Applying SEM in the Higher Education Workplace}

Within the workplace, each layer has a strong influence on employee sustainability and wellness by influencing health behaviors, overall health and well-being. The intrapersonal level is focused on demographics, knowledge, perceptions and attitudes (KPA). The intrapersonal level examines how characteristics such as goals and expectations, gender, religiosity, racial and/ or ethic identities are perceived by colleagues, students and others in the academic environment. Adding to this is the interpersonal level, which includes formal and informal support systems that may influence the individual's KPA. Persons and institutions having direct contact with the faculty member are also part of the interpersonal level. However, it is important to note that family, religious communities, peers in-and-outside of the institution may influence a faculty member's decision to accept a position, how to mitigate potential concerns in the workplace, performance, and employee retention. The relationships between the intrapersonal and interpersonal levels are interrelated; one's experience or knowledge from the interpersonal features can influence the individual and vice versa. Most importantly, stress in the workplace can influence one's overall wellbeing and quality of life. Thus, it is imperative that characteristics from the interpersonal and intrapersonal levels are examined to ensure faculty success and satisfaction.

Diversification within higher education communities includes the opportunity for faculty to express their perspectives or ideas without consequences; it is an opportunity to empower and support underrepresented faculty throughout various levels of position and power. At organizational levels an employee may attempt to actively participate in departmental or university-wide meetings, but rejection or lack of engagement from seasoned peers or chairs may result in stress, and a lack of self-efficacy and/ or low work performance. There is also a concern for loss of power; although the employee may not directly experience the loss of power, the employee is indirectly affected by others who have had a similar experience and outcomes (Bond \& Haynes, 2014). 
Faculty stress and success may be directly influenced by the institutions' community interaction. Organizations and networks may also influence the outcomes of a faculty success and overall well-being, even more for candidates that relocate for a faculty position. Additional factors that are assessed in the organizational level are: social media, legal systems, employment of significant others affect the individual stress-and-health management, employment sustainability and overall success. The outer shell of SEM examines public policies, which includes economics and culture that may influence the employees KPA of the overall institution's governance and how issues are mediated. Although all levels of SEM may be interrelated, the public policies level may have considerable precedence over other levels (Shogren, 2013). Furthermore, the emphasis for the potential of change in each dimension is over time (Bronfenbrenner, 2005; Bronfenbrenner, 1979). The social-ecological model equips leaders with the opportunity to assess and modify factors influencing faculties sense of powerlessness and stress in the workplace, in real-time (chronosystem); application of the chronosystem can be incentivizing as it allows for effective and adequate prevention and mediation of concerns. Additionally, real-time change can be used as a protective factor for faculties desired outcomes; hence, increasing retention and success, while reducing stress and powerlessness.

\section{The Job Stress Intervention Matrix (JSIM)}

We presented two models above: employee socialization (Feldman, 1981) and social ecological (Bronfenbrenner, 2005). Table 1 contains our proposed Job Stress Intervention Matrix (JSIM) as a conceptual framework by categorizing stress management interventions at each stage of employees' socialization (before, onboarding and ongoing) and along the five social ecological levels. The resultant 15 cell matrix serves two purposes. First, the matrix offers a more comprehensive accounting of stress management across multiple sources and work tenure. Second, the lack of comprehensiveness in particular JSIM cells identify opportunities 
to better manage stress. Areas for improvement can be proposed to fill gaps that benefit both employees and organizations. For example, the Anticipatory socialization/Social Ecological Policy JSIM cell can be strengthened with Federal and State legislation that requires greater demographic, diversity, inclusion, Title IX issues, and pending discrimination complains transparency. United States federal executive compensation transparency requirements have increased to help shareholders make more informed decisions (Mishel \& Sabadish, 2012). Similarly, demographic data may help applicants make more informed assessments regarding their fit with potential employers. Women, minorities and other protected classes may find this added information particularly useful in ascertaining fit. Legislation should be enacted that requires state universities and colleges to publish demographic information under the Freedom of Information Act. Private educational institutions can voluntarily publish such information until required to do so.

Using the JSIM, stress reduction interventions are described below. These interventions represent a sample of possible interventions and are not meant to be an exhaustive listing. The individual cells of this matrix contain interventions that were chosen based on the framework of higher education institutions. Most higher education institutions, private and public, are organized in the following hierarchical scheme that guides institutional activity: intrapersonal (Individual), social (Interpersonal), structural (Organizational), external (Community), and policy (Public Policy) (Pusser \& Loss, 2020). The interventions target the particular needs of those in industry the industry of higher education and represent a sample of possible interventions. This matrix is not meant to be an exhaustive list of interventions.

\section{INTERVENTIONS BEST PRACTICES TO ALLEVIATE STRESS}

Research has shown that powerlessness among faculty in higher education is a major case of stress from early on in one's career. The ability to navigate this stress is essential in creating a positive work environment 
and decreasing worksite attrition. As discussed in the JSIM, these stressors vary with the faculty's socialization stage and social system in which they interact within the organization. Due to the variability in roles and stressors it is important to have a holistic approach in reducing stress and improving one's health (Rok, 2011).

\section{Anticipatory}

In higher education, the anticipatory stage consists of persons seeking faculty positions in institutions. In general, job-seeking faculty candidates have diverse backgrounds, some may be experienced academics seeking a new university, those with recently earned doctorates, or persons with field experience outside of academia. Due to their financial obligations, it is expected that new graduates or persons from underrepresented backgrounds are likely to accept lower paying positions in return for job security. This powerlessness and urgency to secure a position in a highly competitive field may be what lands the new faculty member in an unfit position. At the intra-and-interpersonal levels, it is essential for potential faculty to know one's worth in the market, use resources to improve marketability, and do the research to ensure appropriate fit before moving into a position of hire.

\section{Encounter}

Once engaged in the institution, the stressors on the individual change from securing the appropriate position in a well-matched institution, to managing a new position appropriately, based on newly learned expectations. Depending on the institution's expectations regarding faculty position, rank, and field, this workload can vary by course load, research expectations, university service, and community involvement. Managing these various components in higher education can be ambiguous early on in one's career. Previous literature has described strategies to manage this uncertainty and ultimately alleviate stress through workload modifications, entrepreneurial thinking, and mentorship opportunities (Bruce, 2006; Kenny, 2018; Brooks \& Nelson, 2018; Coates \& Goedegebuure, 2012) 
Transitioning to a new academic role, even more when it is at a new higher education institution, may increase one's stress. Onboarding to a new position can be filled with uncertainties, fears and complexities, regardless of the faculty member year of field experience (Ellis et al., 2016). Most institutions require new faculty to participate in an orientation. Orientation program timing, planning and implementation may be costly and ineffective to the institution and new hire. Ineffectiveness may result due to a number of reasons including workplace diversity and inclusiveness, faculty needs, and realistic expectations and goals are not clarified in the early stage of onboarding (Nelson et al., 2016; Wanous, 1973; Premack \& Wanous, 1985). Higher education institutions must go beyond the typical orientation for new hires and strive to identify and address new faculty needs, interests, and motivating factors that reduce stress, and improve pedagogy, student interactions, and overall work performance (Siddiqui et al., 2019).

\section{Workload and Workplace Flexibility}

First, and to an extent second, academic year expectations and experiences for new hires are the most crucial years for many tenured and non-tenured faculty. Experiences, such as workload and flexibility may influence the faculty's overall well-being and quality of life (Olivos-Jara et al., 2014). During the onboarding stage, faculty are becoming acquainted with the overall university culture and department, identifying how to navigate systems and meet the university expectations for contract renewal. Stressors such as academic workload have been widely discussed by many scholars; historically many faculty have noted dissatisfaction of the hours spent on assigned workloads, time for research and expected service and it's interference on familial relationships and self-care (Jacobs \& Winslow, 2004; Nicol \& Yee, 2017). Providing a family-friendly work environment may address stressors (Jacobs \& Winslow, 2004) related to individual and interpersonal levels of the socio-ecological model (SEM). Even more, taking cultural consideration into perspective and providing flexibility such as technology accessible events may address the sense 
of belonging and the interpersonal and community levels of the SEM model (Burnett et al., 2014).

Workload, scholarly and service expectations may vary by institution, such research intensive versus focused-based teaching universities or private versus public and may influence faculty satisfaction (Webber, 2019). However, a common theme noted by many scholars around the globe is the need to revisit determination of workload and recalculate based on current trends and realities, to prevent burnout, reduce turnover rates and improve overall performance (Cohen et al., 2009; Koesten, 2005). A recent study conducted in Australia revealed that more than $1 / 3$ rd (43\%) of time was spent on teaching two courses (Miller, 2019) hence one would postulate double the time (86\%) for faculty required to teach a 4-course load and a greater amount of time if the courses are new preps. Interestingly, new faculty in countries such as Turkey have less service expectations (Apaydin, 2012), increasing faculty's time to teach, and scholarly work.

New faculty may accept overwhelming demands of the higher education industry, as they may be seeking job security and room to grow as a professional (Ylijoki \& Ursin, 2013). The stressors related to daunting workload expectations may not be expressed by new or junior faculty for many reasons, including lack of confidence and confidentiality, fear hostile work environments and being bullied by colleagues and /or administrators, being stereotyped at multiple levels of institutions structure or losing one's appointment (Beckmann et al., 2013; Farhi et al., 2013; Jenkins, 2014); this becomes even more concerning when race and gender are factored in the equation of workload concerns (O’Meara et al., 2017).

Determining workload and expectations is a multifaceted approach that is dependent on factors such as stakeholders' interests, enrollment, resources, as well as university administrators and departmental decisions. Thus, it is evident that when examining the onboarding experience through the SEM, faculty's input on realistic workload must be taken into consideration (Kenny, 2018). Additionally, academic deans 
and department chairs should work collaboratively to identify faculty expectations and supports. Administrators should be cognizant of the type courses taught (intense vs. non-intense) and include buffers (e.g., $10 \%$ ) when determining time for workload and service (Brooks \& Nelson, 2018). Various workload calculation models, including the Simulation Faculty Workload (Blodgett et al., 2018) have been utilized to reassess faculty workload.

Organizational equity is also imperative in improving wellness in the workplace. Not all employees have the same schedules and opportunities to engage in wellness initiatives available. Being conscious of working hours, worksite locations, and home-work life balance, are imperative in preventing intervention-generated inequalities (Smith, et al., 2017).

Because faculty's promotion will be dependent on predetermined expectations (i.e. policies, promotion/portfolio procedures), which may contribute to workplace and individual stress, it becomes increasingly imperative for higher institution administrators to evaluate procedural and distributive justices (Lee \& Raschke, 2018), including policies on how to assist new hires and address their concerns or needs, months prior to orientation day. Furthermore, it is recommended that human resources and departmental chairs communicate and work with new hires, immediately upon receiving their accepted contract, to address concerns that include but are not limited to diversity and inclusion, workplace culture (Wallach et al., 2019), pay schedule, what is expected from the faculty prior to actual start date, as well as identifying a suitable mentor and resources to better prepare for the coming academic year (Foy, 2017).

Additionally, new faculty orientation should be in alignment with the departmental and institutional goals and objectives; the goals should also be transparent to the new faculty during the onboarding stage (Cullen $\&$ Harris, 2008). Even more, the orientation should be an enlightening experience that incorporates motivation and resources, overtime, rather than being compacted into one day (Scott et al., 2016). For instance, 
teaching, planning and preparedness of workload and expectations may be conveyed to the new faculty months to weeks before the launch of a new semester. Although not necessarily a new concept, we recommend prolonging onboarding events throughout the first academic year; this method will likely increase faculty retention and effectively increase opportunity to raise and address concerns (Law et al., 2012). Bruce (2006) describes ways to decrease employee stress in the workplace by improving motivation from an organizational level. Organizations who practice entrepreneurial thinking, making employees feel like partners, have been shown to improve motivation and production in the workplace (Bruce, 2006). Feeling as part of a team through shared authority, rather than solitary work, can be encouraging due to the interpersonal collaboration towards a common goal. Adopting this framework in institutions of higher education can too motivate employees through empowerment, ultimately reducing stress (Rok, 2011).

Narrowing the focus to the individual level, it is evident that interpersonal interactions are essential in higher education to increase the success rate of new faculty (Newell, 1995; Waddell et al., 2016). The ambiguity new faculty members face in regard to teaching, advising, networking, research, publish, committee work, etc. can be tasking and ultimately cause high levels of stress. With the guidance of a mentor, the new faculty member is put in a better position to socialize to the new environment of higher education (Waddell et al., 2016). In the past, mentor-mentee relationships were one-on-one (Blackwell, 1989) however, more current research discusses the effectiveness of multiple mentors to aid in the success of the faculty member (Waddell et al., 2016). Creating positive interpersonal encounters will not only inform the new faculty member on how to navigate the system of higher education, but it has been shown to create a sense of belonging within the workplace (Waddell et al., 2016), both of which will alleviate stress and improve wellness. 


\section{Acquisition}

Ongoing stress management techniques are essential in the long-term wellness of employees (Rok, 2011). These strategies should too be holistic and span across all levels of the socioecological model. The National Wellness Institute (2020) recognizes six dimensions of wellness in the holistic approach to wellness: physical, emotional, occupational, spiritual, intellectual and social. These dimensions are all interrelated and together contribute to overall wellness. Many of the current worksite health promotion programs in higher education institutions focus on more than one dimension of wellness.

One area that is common among programs, thus signifying its importance in higher education employees, is a focus on mental health through stress reduction initiatives. Some of these current practices in worksite wellness programs include group fitness classes (University of North Carolina Greensboro), meditation (Rok, 2011), "personal wellness development" as online and face-to-face "Stress management" classes (University of South Carolina), online stress webinars (University of Alabama), faculty and staff counseling, self-directed stress reduction coaching, and a complete "stress management program" (University of Michigan). Specific topics that these worksite wellness stress programs and classes address are collegiality, managing email stress, stress management tools and resources, importance of self-care, positive coping strategies and resilience, relationship between health and stress, recognizing stress responses, mindfulness, managing anger, and stress and relaxation techniques.

\section{IMPLICATIONS AND CONCLUSIONS}

There are many moderating variables that influence faculties' health and well-being. These variables can be interrelated, leading to a stressful and toxic workplace environment, potentially affecting work performance and overall health of the faculty and others at the institution. Addressing concerns with complete and true anonymity will not only improve 
faculty performance, but it will likely improve faculties' confidence in their administration and institution. When considering supportive health and wellness programs, it is imperative for administrators and program designers to consider alternative options, such as the use of technology and services that are outsourced by third-party organizations.

With increased uncertainty and reduced but competitive higher education job markets, it is increasingly important that higher education holistically examine factors that influence faculty stress, health, work performance, and retention, through the JSIM. Our proposed model equips employers with a conceptual framework in which to apply effective and feasible strategies that improve faculties' workplace experience and wellness. For instance, training for intellectual stimulation may not be sufficient for some faculty. However, coupling resources with adequate mentorship and a phased workload, during the encounter phase, will likely lead to sustainable and less stressful transitions in the acquisition phase (Demšar \& Zabukovec, 2009). Faculty feelings of powerlessness can be reduced, and efficacy with increased inclusion in these strategies whenever possible (Garrin, 2014). Faculty can have greater input in selecting mentors rather than being assigned one during onboarding. Other examples include more in-depth discussions regarding the balance of research, teaching and service leading up to tenure decisions, matching new faculty with possible coauthors based on complementary competencies and interests, and more career development discussions and guidance regarding administrative careers.

Another avenue that may reduce undo stress during an academic career would be increased anonymity in those areas where confidentiality is required. Such situations include sexual and other forms of harassment and challenging personnel decisions.

Workload flexibility is another area that academia already excels, especially relative to other sectors. However, increased awareness and accommodation for working parents, deal with career families and the need for work life balance may be warranted. 


\section{The BRC Academy Journal of Business Vol. 11, No. 1}

In summary, the JSIM presents a systemic outline of workplace health and promotion opportunities throughout the academic life cycle. With faculty and staff input, leadership should prioritize these opportunities based on the school mission, resources and long and short-term needs. Effectively implementing and communicating these initiatives should reduce the sense of powerlessness and stress, while increasing satisfaction, retention, teaching quality and scholarly contributions.

\section{REFERENCES}

Al-Taweel, D., Al-Haqan, A., Bajis, D., Al-Bader, J., Al-Taweel, A. M., AlAwadhi, A., \& Al-Awadhi, F. (2020). Multidisciplinary academic perspectives during the COVID-19 pandemic. The International fournal of Health Planning and Management, 35(6), 1295.

American Institute of Stress (2020a). Workplace Stress. Retrieved February 25, 2020 from https://www.stress.org/workplace-stress.

American Institute of Stress (2020b). Stress is killing you. Retrieved February 25, 2020 from www.stress.org/stress-is-killing-you/.

American Institute of Stress (2020c). 42 Worrying Workplace Stress Statistics. Retrieved September 25, 2020 from https://www.stress.org/ 42-worrying-workplace-stress-statistics

American Psychological Association. (2011). Stress in the Workplace. Retrieved February 25, 2020 from https://www.apa.org/ helpcenter/workplace-stress.

Apaydin, C. (2012). The workload of faculty members: The example of educational faculties in

Turkey.(Report). College Student fournal, 46(1), 203.

Bandura A (2004) Health promotion by social cognitive means. Health Education \& Behavior 31: 143-164. doi: 10.1177/1090198104263660

Beckmann, C. A., Cannella, B. L., \& Wantland, D. (2013). Faculty perception of bullying in 
schools of nursing. fournal of Professional Nursing, 29(5), 287-294. https:// doi.org/10.1016/j.profnurs.2012.05.012

Blackwell, J. E. (1989). Mentoring: An action strategy for increasing minority faculty. Academe, 75(5), 8-14. https://doi.org/10.2307/402 49734

Blodgett, N. P., Blodgett, T., \& Kardong-Edgren, S. E. (2018). A proposed model for simulation

faculty workload determination. Clinical Simulation in Nursing, 18, 2027. https://doi.org/10.1016/j.ecns.2018.01.003

Bond, M. \& Haynes, M. (2014). Workplace Diversity: A Social-Ecological Framework and Policy Implications. Social Issues and Policy Review, 8(1), 167-201. https://doi.org/10.1111/sipr.12005

Bronfenbrenner. (2005). Making human beings human: bioecological perspectives on human

development. Sage Publications: Thousand Oaks.

Bronfenbrenner, U. (1979). The ecology of human development: experiments by nature and design. Harvard University Press: Cambridge.

Brooks, M. J., \& Nelson, M. H. (2018). A preliminary model for faculty workload for a highly

integrated curriculum delivered by team-based learning. Currents in Pharmacy Teaching and Learning, 10(10), 1321-1330. https://doi.org/ 10.1016/j.cptl.2018.07.012

Bruce, A. (2006), How to motivate every employee: 24 proven tactics to spark productivity in the workplace. McGraw-Hill: New York.

Burnett, P., Shemroske, K., \& Khayum, M. (2014). Disrupting faculty service: Using

technology to increase academic service productivity. Administrative Issues fournal: Connecting Education, Practice, and Research, 4(2), 48. https://doi.org/10.5929/2014.4.2.6

Chen, Y.Y., Lin, S.R., \& Kao, C.Y. (2019). Applying Swanson's Theory of Caring to manage powerlessness in an older patient with vasculitis. fournal of Nursing, 66(3), 112-119. doi: 10.6224/JN.201906_66(3).14 
Chen, Y. \& Yang, H. (2010). Nurses' experience helping a fulminant hepatic failure patient face powerlessness. Journal of Nursing, 93-98.

Chhabra, B. (2016). Work role stressors and employee outcomes: Investigating the moderating role of subjective person-organization and person-job fit perceptions in Indian organizations. International Journal of Organizational Analysis, 24(3), 390-414. https:// www.researchgate.net/deref/http\%3A\%2F\%2Fdx.doi.org\%2F10.1108 \%2FIJOA-11-2013-0722

Coates, H. \& Goedegebuure, L. (2012). Recasting the academic workforce: Why the attractiveness of the academic profession needs to be increased and eight possible strategies for how to go about this from an Australian perspective. Higher Education, 64(6), 875-889. https:// doi.org/10.1007/s10734-012-9534-3

Cohen, M. Z., Hickey, J. V., \& Upchurch, S. L. (2009). Faculty workload calculation. Nursing

Outlook, 57(1), 50-59. https://doi.org/10.1016/j.outlook.2008.07.004

Cullen, R., \& Harris, M. (2008). Supporting New Scholars: A LearnerCentered Approach to

New Faculty Orientation. Florida fournal of Educational Administration \& Policy, 2(1), 17. https://files.eric.ed.gov/fulltext/EJ902995.pdf

Coman, C. Tiru, L. G., Mesesan-Schmitz, L., Stanciu, C., \& Bularca, M. C. (2020). Online teaching and learning in higher education during the coronavirus pandemic: Students' perspective. Sustainability, 12(24), 10367. doi:10.3390/su122410367

Demšar, I. \& Zabukovec, V. (2009). "Sindrom izgorelosti pri učiteljih" (Teacher burnout syndrome), Pedagoška obzorja - Didactica Slovenica , 10(1), 134-150.

Darabi, M., Macaskill, A., \& Reidy, L. (2017). A qualitative study of the UK academic role: Positive features, negative aspects and associated stressors in a mainly teaching-focused university. Fournal of Further and Higher Education, 41(4), 566-580. https://doi.org/10.1080/03098 77X.2016.1159287

Ellis, A. M., Bauer, T. N., Mansfield, L. R., Erdogan, B., Truxillo, D. M., \& Simon, L. S. (2015). Navigating uncharted waters: Newcomer 
socialization through the lens of stress theory. Fournal of Management, 41(1), 203-235. https://doi.org/10.1037/apl0000201

Faisal, F., Noor, N., \& Khair, A. (2019). Causes and consequences of workplace stress among Pakistan university teachers. Bulletin of Education and Research, 41(3), 45-60.

Farhi, E., Lerner, J., \& Tirole, J. (2013). Fear of rejection? Tiered certification and transparency.

The RAND fournal of Economics, 44(4), 610-631.

Feldman, D. C. (1981). The multiple socialization of organization members. The Academy of Management Review, 309-318. https://doi.org/10.54 65/amr.1981.4287859

Feldman, D. C. (1976). "A Practical Program for Employee Socialization," Organizational Dynamics, 5, 64-80. https://doi.org/10.1016/0090-26 16(76)90055-3

Feldman, D. C. (1967). A Contingency Theory of Socialization. Administrative Science Quarterly, 21(3), 434-435. https://www.jstor. org/stable/2391853

Flaherty, C (2020, November 19). Faculty pandemic stress is now chronic. Retrieved January 4,

2021, from https://www.insidehighered.com/news/2020/11/19/facultypandemic-stress-now-chronic

Foy, C. (2017). Identifying barriers and pathways to success for new occupational therapy

faculty members: A pilot survey. Occupational Therapy in Health Care, 31(4), 329-340. https://doi.org/10.1080/07380577.2017.1354269

Garrin, J. M. (2014). Self-Efficacy, Self-Determination, and Self-Regulation: The Role of the Fitness Professional in Social Change Agency. Journal of Social Change, 6(1), 41-54. https://doi-org.ezproxy.oswego.edu/1 0.5590/JOSC.2014.06.1.05

Glasberg, A.L., Norberg, A., \& Söderberg, A. (2007). Sources of burnout among healthcare employees as perceived by managers. fournal of Advanced Nursing, 60(1), 10-19. doi: 10.1111/j.1365-2648.2007.04370.x 
Greenberg, A. (2014). Start asking unique interview questions. Retrieved February 24, 2020 from http://www.recruitingdivision.com/startasking-unique-interview-questions-2.

Hurley, J., Hutchinson, M., Bradbury, J., \& Browne, G. (2016). Nexus between preventive policy inadequacies, workplace bullying, and mental health: Qualitative findings from the experiences of Australian public sector employees. International fournal of Mental Health Nursing, 25(1), 12-18.

Jacobs, J. A. \& Winslow, S. E. (2004). Overworked faculty: Job stresses and family

demands. (Author Abstract). The Annals of the American Academy of Political and Social Science, 596, 104. https://doi.org/10.1177/000271 6204268185

Jenkins, R. (2014). The lack of public intellectuals at community colleges: Fear and disrespect

keep faculty members from speaking out on major issues. The Chronicle of Higher Education, 60(28).

Kangos, K. A., Ellis, M. V., Berger, L., Corp, D. A., Hutman, H., Gibson, A., \& Nicolas, A. I. (2018). American psychological association guidelines for clinical supervision: Competency-based implications for supervisees. The Counseling Psychologist, 46(7), 821-845. doi:10.1177/0011000018807128

Kenny, J. (2018). Re-empowering academics in a corporate culture: An exploration of workload

and performativity in a university. (Article). Higher Education, 75(2), 365. https://doi.org/10.1007/s10734-017-0143-z

Kinchen, E. V. \& Victoria, L. (2019). Nursing students' attitudes and use of holistic therapies for stress relief. Journal of Holistic Nursing, 37(1), 6-17. http://dx.doi.org/10.1177/0898010118761910

Knežević, J. \& Krstić, T. (2019). The role of basic psychological needs in the perception of job insecurity. Archives of Industrial Hygiene \& Toxicology / Arhiv Za Higijenu Rada I Toksikologiju, 70(1), 54-59. 
Koesten, J. (2005). Reducing stress and burnout for financial planners. Fournal of Financial Planning, 18(10), 64-66, 68, 70, 72, 74.

Konopaske, R. K., Ivancevich, J. M., \& Matteson, M. T. (2018). Organizational Behavior and Management. McGraw-Hill: New York.

LaPonsie, M. (2020). 16 Low-Stress Jobs. There are no totally stressfree jobs, but these low-stress careers come pretty close. Retrieved December 30, 2020 from https://money.usnews.com/careers/bestjobs/slideshows $/ 16$-low-stress-jobs? slide $=18$

Law, A. V., Jackevicius, C., Le, J., Murray, W. I., Hess, K., Pham, D. Q. \& Min, D. I. (2012).

Impact of a faculty orientation and development committee. (SPECIAL ARTICLES). American fournal of Pharmaceutical Education, 76(1). https://doi.org/10.5688/ajpe7613

Lee, M. T., \& Raschke, R. L. (2018). Freeing "workplace prisoners" in higher education:

Configurations for collective knowledge building and educational value decisions. Fournal of Business Research, 88, 443-448. https://doi.org/ 10.1016/j.jbusres.2018.01.022

Lim, S., Powell, T. W., Xue, Q., Towe, V. L., Taylor, R. B., Ellen, J. M., \& Sherman, S. G. (2018). Exploratory and confirmatory factor analyses and invariance assessment of the perceived powerlessness scale among youth in Baltimore. Fournal of Health Psychology,135910531876934. doi:10.1177/1359105318769349

Liu, C. \& Li, H. (2018). Stressors and stressor appraisals: The moderating effect of task efficacy. Fournal of Business and Psychology, 33(1), 141-154.

Marais, L., Lantheaune, S., Fiaut, R., Shankland, R. (2020). Mindfulness-Based programs

improve psychological flexibility, mental health, well-being, and time management in academics. European fournal of Investigation in Health, Psychology and Education, 10(73), 1035-1050. https://doi.org/10.339 0/ejihpe10040073 
Miller, J. (2019). Where does the time go? An academic workload case study at an Australian

university. Journal of Higher Education Policy and Management, 41(6), 633-645. https://doi.org/10.1080/1360080X.2019.1635328

Miller, L. H., Smith, A. D., \& Rothstein, L. (1994). The Stress Solution. Pocket Books: New York.

Mishel, L. \& Sabadish, N. (2012). CEO pay and the top 1\%: how executive compensation and finance-sector pay inequality. Economic Policy Institute, 331, 1-7.

Mustanski, B., Birkett, M., Greene, G., Hatzenbuehler, M., \& Newcomb, M. (2014). Envisioning an America without sexual orientation inequities in adolescent health. American fournal of Public Health (1971), 104(2), 218-225.

National Institute of Wellness. The six dimensions of wellness. Retrieved on April 15, 2020 from https://www.nationalwellness.org/page/Six _ Dimensions

Nelson, A., Anis-Abdellatif, M., Larson, J., Mulder, C., \& Wolff, B. (2016). New faculty

orientation: Discussion of cultural competency, sexual victimization, and student behaviors. Journal of Continuing Education in Nursing, 47(5), 228. https://doi.org/10.3928/00220124-20160419-09

Nelson, D. L. (1987). Organizational socialization: A stress perspective: SUMMARY. Journal of Occupational Behavior (1986-1998), 8(4), 311.

Newell, S. (1995). The Healthy Organization: Fairness, Ethics and Effective Management. Routledge: London, New York.

Newton, J., Dooris, M., \& Wills, J. (2016). Healthy universities: an example of a whole-system health-promoting setting. Global Health Promotion, 23(1_suppl), 57-65. https://doi.org/10.1177/17579759156 01037

Newton, C.J. \& Jimmieson, N.L. (2009). Subjective fit with organizational culture: An investigation of moderating effects in the work stressoremployee adjustment relationship. International fournal of Human 
Resource management, 26(8), 1770-1789. https://doi.org/10.1080/095 85190903087198

Nicol, D. J., \& Yee, J. A. (2017). "Reclaiming Our Time": Women of color faculty and radical

self-care in the academy. Feminist Teacher, 27(2-3), 133-156. https://doi. org/10.5406/femteacher.27.2-3.0133

Olivos-Jara, P., Galán-Carretero, A., \& Santos-Segovia, A. (2014). Relations between

workload, work attitudes and psychological variables in Spanish university professors. Procedia - Social and Behavioral Sciences, 140, 128-132. https://doi.org/10.1016/j.sbspro.2014.04.397

O’Meara, K., Kuvaeva, A., Nyunt, G., Waugaman, C., \& Jackson, R. (2017). Asked more often:

Gender differences in faculty workload in research universities and the work interactions that shape them. American Educational Research Journal, 54(6), 1154. https://doi.org/10.3102/0002831217716767

Özer, Ö., Uğurluoğlu, Ö., Saygıll, M., \& Sonğur, C. (2019). The impact of work alienation on organizational health: A field study in the health sector. International fournal of Healthcare Management, 12(1), 18-24.

Paula, L. \& Grinfelde, A. (2018). The role of mentoring in professional socialization of novice teachers. Problems of Education in the 21st Century, 76(3), 364-379. https://login.ezproxy.oswego.edu/login?url= https://search.proquest.com/docview/2343794366?accountid=13025

Pesis-Katz, I., Smith, J. A., Norsen, L., DeVoe, J., \& Singh, R. (2020). Reducing cardiovascular disease risk for employees through participation in a wellness program. Population Health Management, 23(3), 212-219. https://doi.org/10.1089/pop.2019.0106

Premack, S. L. \& Wanous, J. P. (1985). A meta-analysis of realistic job preview experiments. Fournal of Applied Psychology, 70(4), 706-719.

Pusser, B. \& Loss, C.P. (2020). Colleges and Organizational Structure of Universities. Retrieved December 31, 2020 from https:// education.stateuniversity.com/pages/1859/Colleges-UniversitiesOrganizational-Structure.html 
Rayner, G., Blackburn, J., Edward, K., Stephenson, J., \& Ousey, K. (2019). Emergency department nurse's attitudes towards patients who selfharm: A meta-analysis. International fournal of Mental Health Nursing, 28(1), 40-53.

Renzulli, K.A. (2019). The least stressful job in America pays \$71,410here are the other 9. Retrieved December 30, 2020 from https:// www.cnbc.com/2019/03/06/careercast-the-10-least-stressful-jobs-inamerica.html

Rizun, M., \& Strzelecki, A. (2020). Students' acceptance of the COVID-19 impact on shifting higher education to distance learning in Poland. International fournal of Environmental Research and Public Health, 17(18), 6468. doi:10.3390/ijerph171864

Rizzo, J. R., House, R.J., \& Lirtzman, S.L. (1970). Role conflict and ambiguity in complex organizations. Administrative Science Quarterly, 15(2), 150-162.

Rok, M (2011). Stress and stress management in a higher education tourism institution. Tourism and Hospitality Management, 17(2), 279-290.

Rosa, E. \& Tudge, J. (2013). Urie Bronfenbrenner's Theory of Human Development: Its evolution from ecology to bioecology. Fournal of Family Theory \& Review, 5(4), 243-258. https://doi.org/10.1111/jftr. 12022

Scott, W., Lemus, D., Knotts, G., \& Oh, J. (2016). Why learner-centered new faculty

orientations matter: Organizational culture and faculty retention. fournal of Faculty Development, 30(1), 15. http://dx.doi.org/10.24059/olj.v21 i4.1273

Shogren, K.A. (2013). A Social-Ecological analysis of the selfdetermination literature. Fournal of Intellectual \& Developmental Disability, 51(6): 496-511. https://doi.org/10.1352/1934-9556-51.6.496

Siddiqui, M., Papanagnou, D., Bruno, S., \& Novielli, K. (2019). The case for revamping new 
faculty orientation: Integrating case-based learning into faculty onboarding. MedEdPORTAL: The fournal of Teaching and Learning Resources, 15, 10843. https://doi.org/10.15766/mep_2374-8265.10843

Smith, S.A., Visram, S., O’Malley, C., Summerbell, C., Araujo-Soares V., Hillier-Brown, F., \& Lake, A.A. (2017). Designing equitable workplace dietary interventions: Perceptions of intervention deliverers. $B M C$ Public Health, 17(808), 1-8.

Society for Human Resource Management (2015). Stressed Out at Work? Your Job Could Be on This List- Top 10 most and least stressful jobs for 2015. Retrieved December 30, 2020 from https://www.shrm.org/ hr-today/news/hr-news/pages/top-10-most-least-stressful-jobs-for2015.aspx.

Street, T. D., \& Lacey, S. J. (2019). Accounting for employee health: The productivity cost of leading health risks. Health Promotion fournal of Australia, 30(2), 228-237.

Substance Abuse and Mental Health Services Administration (SAMHSA) (2016). Creating a healthier life: A step-by-step guide to wellness. Retrieved on May 7, 2020 from file:///Users/elizabeth/Downloads/sma16-4958.pdf

Swick, K., \& Williams, R. (2006). An analysis of Bronfenbrenner's BioEcological perspective for early childhood educators: Implications for working with families experiencing stress. Early Childhood Education fournal, 33(5), 371-378. https://doi.org/10.1007/s10643-006-0078-y

Vander Elst, T., Van den Broeck, A., De Witte, H., \& De Cuyper, N. (2012). The mediating role of frustration of psychological needs in the relationship between job insecurity and work-related well-being. Work \& Stress, 26(3), 252-271.

Waddell, J., Martin, J., Schwind, J., \& Lapum, J. (2016). A faculty-cased mentorship circle: Positioning new faculty for success. Canadian Fournal of Higher Education, 46(4), 60-75. Retrieved on April 18th, 2020 from https://files.eric.ed.gov/fulltext/EJ1128609.pdf

Wallach, A., McCrickard, M., Eliasz, K. L., \& Hochman, K. (2019). An experiential faculty 


\section{The BRC Academy Journal of Business Vol. 11, No. 1}

orientation to set communication standards. Medical Education, 53(5), 512-513. https://doi.org/10.1111/medu.13867

Wallerstein, N. (1992). Powerlessness, empowerment, and health: Implications for health promotion programs. American fournal of Health Promotion, 6(3), 197. https://doi.org/10.4278/0890-1171-6.3.197

Walkington, L. (2017). How far have we really come? Black women faculty and graduate students' experiences in higher education. Humboldt fournal of Social Relations, 39, 51-65.

Wang, M., Zhan, Y., McCune, E., \& Truxillo, D. (2011). Understanding newcomers' adaptability and work-related outcomes: Testing the mediating roles of perceived p-e fit variables. Personnel Psychology, 64(1), 163-189. https://doi.org/10.1111/j.1744-6570.2010.01205.x

Wanous, J. P. (1973). Effects of a realistic job preview on job acceptance, job attitudes, and job survival. Journal of Applied Psychology, 58(3), 327-332. https://doi.org/10.1037/h0036305

Webber, K. L. (2019). Does the environment matter? Faculty satisfaction at 4-year colleges and

universities in the USA. Higher Education, 78(2), 323-343. https://doi. org/10.1007/s10734-018-0345-z

Weeks, W. A. \& Fournier, C. (2010). The impact of time congruity on salesperson's role stress: A person--job fit approach. fournal of Personal Selling \& Sales Management, 30(1), 73-90. https://doi.org/1 0.2753/PSS0885-3134300105

Ylijoki, O.-H., \& Ursin, J. (2013). The construction of academic identity in the changes of

Finnish higher education. Studies in Higher Education, 38(8), 1135. https:// doi.org/10.1080/03075079.2013.833036

\section{Citation Information}

Friedman, Barry A., Elizabeth Keida, and Najah Zaaeed. "The Job Stress Intervention Matrix: A New Conceptual Framework for Higher Education 
in the Post-COVID World ." The BRC Academy fournal of Business 11, no. 1 (2021): 57-85. https://dx.doi.org/10.15239/j.brcacadjb.2020.11.01.ja03

\section{Web APPE NDIX}

A web appendix for this paper is available at: https://dx.doi.org/10.15239/ j.brcacadjb.2021.11.01.wa03 